\title{
Frequency Response Analysis of Inverter Circuit
}

\author{
I. Ye. Korotyeyev, Dr Hab., Prof., ORCID 0000-0002-7990-5413 \\ e-mail i.korotyeyev@iee.uz.zgora.pl \\ Institute of Electrical Engineering www.iee.uz.zgora.pl \\ University of Zielona Góra uz.zgora.pl \\ Zielona Góra, Poland
}

\begin{abstract}
This paper deals with analysis of steady-state processes in an inverter circuit. Since a configuration of the inverter circuit is changed processes in such a circuit are described by differential equations with variable coefficients. It is supposed that the inverter circuit changes periodically. The Lyapunov's transform, a method of expanding of a differential equation to an equation in partial derivatives and the two dimensional Laplace transform are used to find a steady-state process. The transfer function and frequency response for processes running in the inverter circuit are introduced. The steady-state process is obtained in the form of the double Fourier series. An example of an inverter is considered and a set of frequency responses is presented.
\end{abstract}

Ref. 6, fig. 6.

Key words - expanding of differential equation; Lyapunov's transform; double Fourier series; frequency response.

\section{INTRODUCTION}

Processes in inverter circuits are often described by differential equations with periodical coefficients. This is connected with the presence of switching elements in inverter circuits and periodic control signals.

Power sources govern the work of inverter circuits. Both power sources and control signals determine nature of processes. In many cases steady-state voltages and currents can be presented by the Fourier series. If periods of power sources and control signals are incommensurable then a steady-state process in domain of one variable of time does not exist.

A definition of frequency response [1] is based on steady-state processes running in a linear circuit with constant parameters. In the circuit with time-varying elements we have a mutual effect of influence both power sources and control signals on a load. Therefore in such systems we cannot use the classic definition of frequency response.

Let's assume that power sources and control systems are independent. Expanding differential equations in a domain of two independent variables of time [2] we can find steady-state process. In that case we can find dependences describing frequency characteristics as a function of a source frequency.

The subject of this article is to spread definition of frequency response for circuit with time-varying elements. The method is based on an expanding of a differential equation by introducing an additional independent time variable. A steady state process is obtained by using the two dimensional Laplace transform and is represented by the double Fourier series. A set of frequency responses is obtained for an inverter with variable structure.

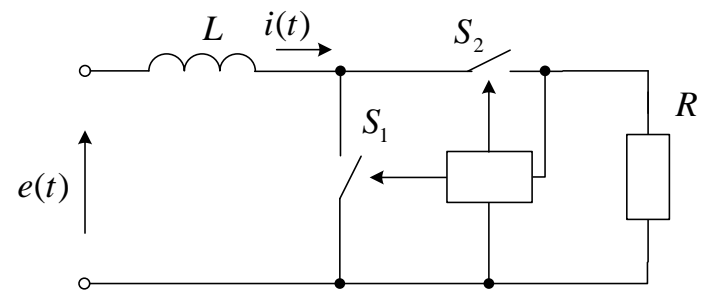

Fig. 1 Topology of the inverter

\section{MATHEMATICAL MODEL}

Let us find a steady-state process in the circuit of the inverter presented in Fig. 1.

The switches $S_{1}$ and $S_{2}$ are periodically turned on and off at the same instant. Switches work with the period $\Theta$ as shown in Fig. 2 alternately, if $S_{1}$ is on $S_{2}$ is off (when $s(t)=1 S_{1}$ is closed and $S_{2}$ is open).

The differential equation describing processes in the circuit has the form

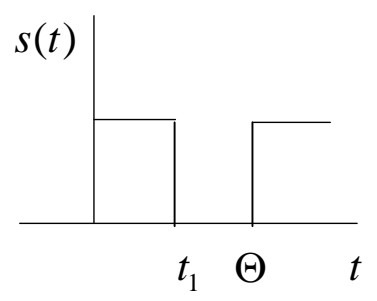

Fig. 2 Switching function 


$$
L \frac{d i(t)}{d t}=-R(t) i(t)+e(t),
$$

where $R(t)=\left\{\begin{array}{c}R_{1}, n \Theta \leq t \leq n \Theta+t_{1}, \\ R_{2}, n \Theta+t_{1} \leq(n+1) \Theta,\end{array} \quad R_{1} \quad\right.$ is equal to the sum of resistances of an inductor, a switch $S_{1}$ and a load $R ; R_{2}$ is equal to the sum of resistances of the inductor, a switch $S_{2}$ and the load $R ; n=0,1, \ldots$, $e(t)=e(t+T), T$ is a period of a power source.

We assume that periods of a source voltage $e(t)$ and the control signal are incommensurable. In that case a steady-state process (1) is not periodic.

In order to obtain a periodic steady-state solution of (1) let us expand the domain of the differential equation (1) from one independent variable of time $t$ to two independent variables of time $t$ and $\tau$ as follows [2]:

$$
L \frac{\partial i(t, \tau)}{\partial t}+L \frac{\partial i(t, \tau)}{\partial \tau}=-R(\tau) i(t, \tau)+e(t) .
$$

Using Lyapunov’s transform [3]

$$
i(t, \tau)=F(\tau) \cdot y(t, \tau),
$$

we transform differential equation (2) with the periodical coefficient $R(\tau)$ to a differential equation with a constant coefficient

$$
\frac{\partial y(t, \tau)}{\partial t}+\frac{\partial y(t, \tau)}{\partial \tau}=K \cdot y(t, \tau)+N(\tau) \cdot \frac{e(t)}{L},
$$

where $F(\tau)=F(\tau+\Theta)$ is a Lyapunov's function; $y(t, \tau)$ is a new state variable, $N(\tau)$ is a function which is inverse to $F(\tau), N(\tau)=1 / F(\tau)$.

A constant $K$ and the function $F(\tau)$ are determined from the equation

$$
\frac{d F(\tau)}{d \tau}=\frac{R(\tau)}{L} F(\tau)-F(\tau) K
$$

and conditions $F(\tau)=F(\tau+\Theta)$ and $F(0)=1$.

The function $F(\tau)$ is a piecewise continuous function. Solving the equation (5) in the interval $0 \leq \tau \leq t_{1}$ gives

$$
F(\tau)=e^{\alpha_{1} \tau} e^{-K \tau},
$$

and in the interval $t_{1} \leq \tau \leq \Theta$ gives

$$
F(\tau)=e^{\alpha_{2}\left(\tau-t_{1}\right)} e^{\alpha_{1} t_{1}} e^{-K \tau},
$$

where $\alpha_{1}=-\frac{R_{1}}{L}, \alpha_{2}=-\frac{R_{2}}{L}$.

The constant $K$ is determined by using conditions $F(\tau)=F(\tau+\Theta)$ and $F(0)=1$ :

$$
K=\frac{1}{\Theta} \ln \left[e^{\alpha_{2}\left(\Theta-t_{1}\right)} e^{\alpha_{1} t_{1}}\right]=\frac{\alpha_{2}\left(\Theta-t_{1}\right) \alpha_{1} t_{1}}{\Theta} .
$$

The differential equation (4) is the partial differential equation and defines the function $y(t, \tau)$ in the domain of two variables. In this domain a steady-state process exists , i.e. $y_{s}(t, \tau)=y_{s}(t+T, \tau+\Theta)$.

\section{DETERMINATION OF STEADY-STATE PROCESS}

In order to find a solution of (4) let us use the two dimensional Laplace transform [4]:

$$
F(s, q)=\int_{0}^{\infty} \int_{0}^{\infty} f(t, \tau) e^{-s t-q \tau} d \tau d t .
$$

Taking the transform of every term in the equation (4) we obtain:

$$
s Y(s, q)+q Y(s, q)=K \cdot Y(s, q)+N(q) \cdot E(s) / L,(6)
$$

where $s, q$ are complex variables; $Y(s, q), N(q), E(s)$ are Laplace transforms of $y(t, \tau), N(\tau)$ and $e(t)$.

Since the function $N(\tau)$ is periodical, then the transform takes the form

$$
N(q)=\frac{\int_{0}^{\Theta} N(\tau) e^{-q \tau} d \tau}{1-e^{-q \Theta}}=\frac{N^{\prime}(q)}{1-e^{-q \Theta}} .
$$

Solving (6) we obtain:

$$
Y(p, q)=\frac{N(q) \cdot E(s)}{L[(s+q)-K]} .
$$

In order to find the current $i(t, \tau)$ we must apply Lyapunov's transform. Taking the Laplace transform of (3) we obtain:

$$
I(s, q)=F(q) * Y(s, q),
$$

where $*$ is sign of the convolution in the frequency domain [5]:

$$
I(s, q)=\frac{1}{2 \pi j} \int_{c-j \infty}^{c+j \infty} F(p) Y(s, q-p) d p .
$$

Taking into account (7) and (8) we obtain following expression:

$$
I(s, q)=F(q) * \frac{N(q) \cdot E(s)}{L[(s+q)-K]},
$$

where $I(s, q)$ is the transform of $i(t, \tau)$.

\section{FREQUENCY RESPONSES}

Let us define the transfer function of the circuit as the quotient of $I(s, q)$ to $E(s)$

$$
T(s, q)=\frac{I(s, q)}{E(s)} .
$$

Using (9) we obtain:

$$
T(s, q)=F(q) * \frac{N(q)}{L[(s+q)+K]} .
$$


Since the function $F(\tau)$ is periodical, then the transform takes the form

$$
F(q)=\frac{\int_{0}^{\Theta} F(\tau) e^{-q \tau} d \tau}{1-e^{-q \Theta}}=\frac{F^{\prime}(q)}{1-e^{-q \Theta}} .
$$

Let us find the convolution in (10). Calculating residues with respect to poles of the transform $F(q)$ yields:

$$
T(s, q)=\frac{1}{L \Theta\left(1-e^{-q \Theta}\right)} \cdot \sum_{i=-\infty}^{\infty} \frac{F^{\prime}\left(q_{i}\right) N^{\prime}\left(q-q_{i}\right)}{\left(q-q_{i}+s\right)-K}
$$

where $q_{i}=j \frac{2 \pi i}{\Theta}$ is roots of the equation

$$
\begin{gathered}
1-e^{-q \Theta}=0 ; \\
i=0, \pm 1, \pm 2, \ldots
\end{gathered}
$$

It should be noted that the residues with respect to poles of $F^{\prime}(q)$ are equal to zero.

In order to introduce the definition of frequency responses for the inverter let us find the steady-state process of the voltage $e(t)=\cos (\omega t)$. Since the transform of that voltage is

$$
E(s)=\frac{s}{s^{2}+\omega^{2}},
$$

the transform of the current yields

$$
I(s, q)=F(q) * \frac{N(q) \cdot s}{L[(s+q)-K]\left(s^{2}+\omega^{2}\right)} .
$$

Using (11) we obtain

$$
\begin{gathered}
I(s, q)=\frac{s}{L \Theta\left(1-e^{-q \Theta}\right)\left(s^{2}+\omega^{2}\right)} . \\
\sum_{i=-\infty}^{\infty} \frac{F^{\prime}\left(q_{i}\right) N^{\prime}\left(q-q_{i}\right)}{\left[\left(q-q_{i}+s\right)-K\right]} .
\end{gathered}
$$

The steady-state process is determined with respect to poles corresponding to forced functions, i.e. the power supply $s= \pm j \omega$ and control signal $q_{n}=j \frac{2 \pi n}{\Theta}$

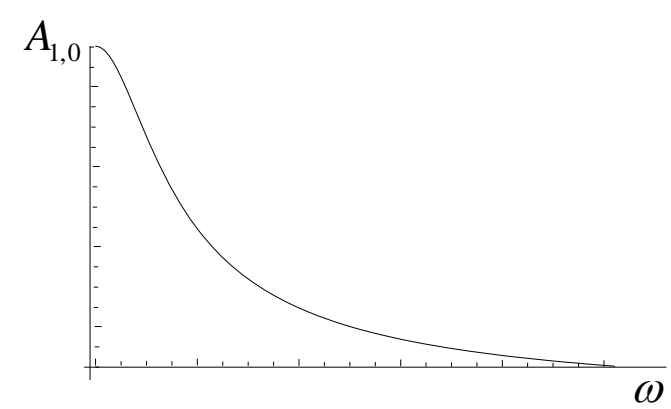

Fig. 3 Amplitude response for $n=0$ $n=0, \pm 1, \pm 2, \ldots)$. After calculation residues we obtain the steady-state current in the form of the double Fourier series [6]:

$$
i_{S}(t, \tau)=\sum_{\substack{m=-1 \\ m \neq 0}}^{1} \sum_{n=-\infty}^{\infty} C_{m, n} e^{j(m \omega t+n \Omega \tau)},
$$

where $\Omega=\frac{2 \pi}{\Theta}$,

$$
C_{m, n}=\frac{m}{2 L \Theta^{2}} \sum_{i=-\infty}^{\infty} \frac{F^{\prime}\left(q_{i}\right) N^{\prime}\left(q_{n}-q_{i}\right)}{\left(q_{n}-q_{i}+j \omega m\right)-K} .
$$

Since $\mathrm{m}$ and $\mathrm{n}$ take positive and negative values terms in (12) can be rearranged as follows

$$
\begin{aligned}
& C_{1, n} e^{j(\omega t+n \Omega \tau)}+C_{-1,-n} e^{-j(\omega t+n \Omega \tau)}+ \\
& +C_{1,-n} e^{j(\omega t-n \Omega \tau)}+C_{-1, n} e^{j(-\omega t+n \Omega \tau)}=
\end{aligned}
$$

$=A_{1, n} \sin \left(\omega t+n \Omega \tau+\phi_{1, n}\right)+A_{1,-n} \sin \left(\omega t-n \Omega \tau+\phi_{1,-n}\right)$, where $A_{1, n}=2 \cdot\left|C_{1, n}\right|, A_{1,-n}=2 \cdot\left|C_{1,-n}\right|, \phi_{1, n}=\arg C_{1, n}$, $\phi_{1,-n}=\arg C_{1,-n}$.

We shall call $A_{1, n}$ and $A_{1,-n}$ amplitude responses and $\phi_{1, n}$ and $\phi_{1,-n}$ phase responses. As one can see the frequency responses are a set of characteristics.

\section{RESULTS OF CALCULATION}

Let us draw the amplitude and phase responses of the circuit for parameter values: $R_{1}=0.5 \Omega, R_{2}=1.4 \Omega$, $i=4, L=0.01 H, \Theta=0.002 s, t_{1}=0.3 \cdot \Theta s$. The obtained frequency responses are shown in Fig. 3 - Fig. 6.

One can see that the amplitude response $A_{1,0}$ and phase response $\phi_{1,0}$ for first harmonic behave as well as a frequency response of a series resistor inductor circuit to a sinusoidal source.

For some frequencies the same values for frequency responses are obtained.

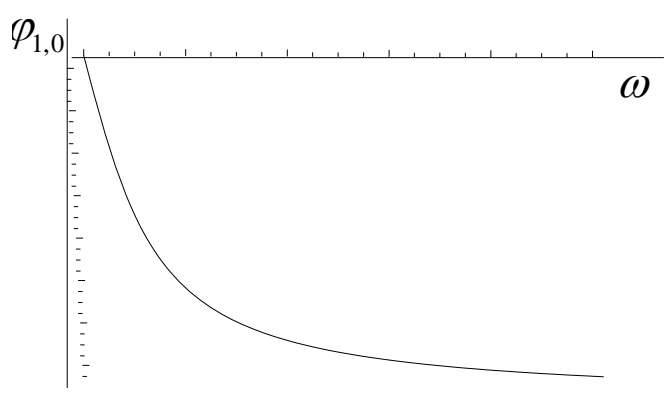

Fig. 4 Phase response for $n=0$ 


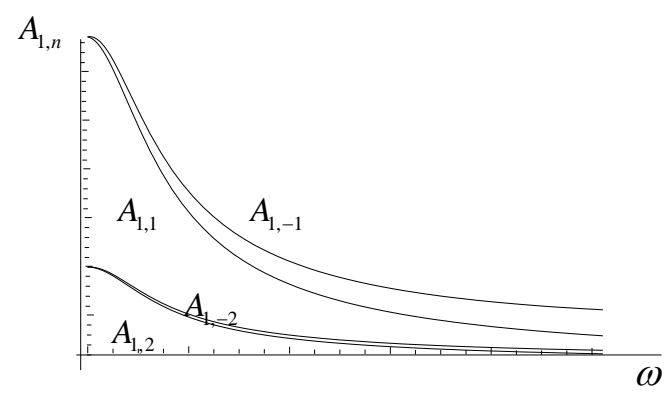

Fig. 5 Amplitude responses for $n= \pm 1$ and $n= \pm 2$

One can see that the amplitude response $A_{1,0}$ and phase response $\phi_{1,0}$ for first harmonic behave as well as a frequency response of a series resistor inductor circuit to a sinusoidal source.

For some frequencies the same values for frequency responses are obtained.

\section{CONCLUSION}

In this paper the steady-state processes in time-varying circuit have been considered. The processes in the inverter with periodical structure have been described by the differential equation with the periodical coefficient. This equation has been extended to the partial differential equation. Using Lyapunov's transform the partial differential equation with periodical coefficient has been transformed to the equation with constant coefficient. Then the two dimensional Laplace transform has been used and the solution has been represented by the double Fourier series. The set of frequency responses for circuit with periodical structure has been defined. These characteristics are the response of the circuit to

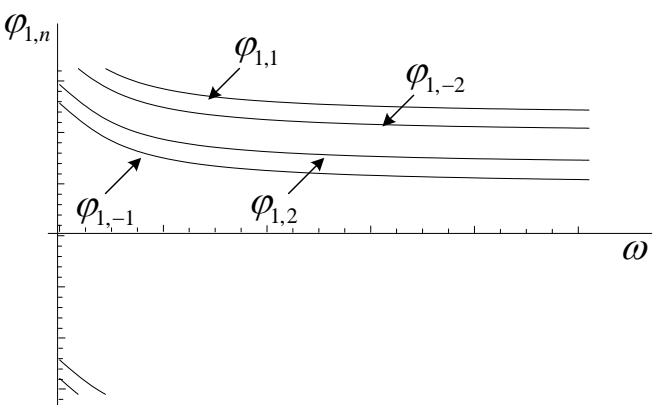

Fig. 6 Phase responses for $n= \pm 1$ and $n= \pm 2$

the sinusoidal signal. The example of the frequency responses for the inverter is presented.

\section{REFERENCES}

[1] Charles K. Alexander; Matthew N. O. Sadiku, Fundamentals of Electric Circuits, 5th Edition ed., New York: Estados Unidos: McGraw-Hill, 2013, p. 950. ISBN: 978-0073380575

[2] I. Korotyeyev; V. Zhuikov; R. Kasperek, Electrotechnical systems. Calculation and analysis with Mathematica and PSpice, CRC Press, 2010. E-ISBN: 978-1-4200-8710-9

[3] F. R. Gantmacher, The Theory of Matrices, New York: Chelsear, 1977, p. 276.

[4] V. A. Ditkin; A. P. Prudnikov, Operational Calculus in Two Variables and its Application, London: Pergamon Press, 1962.

[5] G. Doetsch, Anleitung zum praktischen Gebrauch der Laplacetransformation und der Z-transformation [Instructions on the practical use of the Laplace transformation and the Ztransformation], Munchen/Wien: R. Oldenbourg, 1967.

[6] G. P. Tolstov, Foutier Series, Mineola, New York: Dover Publications Inc., 1976.

Надійшла до редакції 15 червня 2017 р.

УдК 621.314

\section{Аналіз частотних характеристик ланцюга інвертора}

Коротєєв I. Є., д.т.н., проф., ORCID 0000-0002-7990-5413

e-mail i.korotyeyev@iee.uz.zgora.pl

Інститут Промислової електроніки www.iee.uz.zgora.pl

Зеленогурский университет uz.zgora.pl

Зелена Гора, Польща

Реферат-Стаття присвячена аналізу усталеного процесу в ланцюзі інвертора. Оскільки конфігурація ланцюга інвертора змінюється, процеси в такому колі описуються диференційними рівняннями зі змінними коефіцієнтами. 
Передбачається, що ланцюг інвертора змінюється періодично. Для знаходження усталеного процесу використовуються метод розширення звичайного диференційного рівняння до рівняння в частинних похідних, перетворення Ляпунова та двовимірне перетворення Лапласа. Для процесів, що протікають в ланцюзі інвертора, вводиться поняття передавальної функції і частотних характеристик. Встановлений процес отриманий у вигляді подвійного ряду Фур'є. Як приклад розглянуто інвертор, для якого представлені частотні характеристики.

Бібл. 6, рис. 6.

Ключові слова - розиирення диференціального рівняння; перетворення Ляпунова; подвійний ряд Фур'є; частотна характеристика.

УДК 621.314

\section{Анализ частотных характеристик цепи ин- вертора}

Коротеев И. Е., д.т.н., проф., ORCID 0000-0002-7990-5413

e-mail i.korotyeyev@iee.uz.zgora.pl

Институт Промышленной электроники www.iee.uz.zgora.pl

Зеленогурский университет uz.zgora.pl

Зелена Гора, Польша

Реферат-Эта статья посвящена анализу установившегося процесса в цепи инвертора. Поскольку конфигурация цепи инвертора изменяется, процессы в такой цепи описываются дифференциальными уравнениями с переменными коэффициентами. Предполагается, что цепь инвертора изменяется периодически. Для нахождения установившегося процесса используются метод расширения обыкновенного дифференциального уравнения до уравнения в частных производных, преобразование Ляпунова и двумерное преобразование Лапласа. Для процессов, протекающих в цепи инвертора, вводится понятие передаточной функции и частотных характеристик. Установившийся процесс получен в виде двойного ряда Фурье. В качестве примера рассмотрен инвертор, для которого представлены частотные характеристики.

Библ. 6, рис. 6.

Ключевые слова - расиирение дифференциального уравнения; преобразование Ляпунова; двойной ряд Фурье; частотная характеристика. 